ZatącZnil

\title{
DZIAŁALNOŚĆ TOWARZYSTWA POLSKA SZTUKA STOSOWANA (1901-1913) - PRÓBY NAWIAZZANIA WSPÓŁPRACY MIĘDZY PRODUCENTAMI, PROJEKTANTAMI I ODBIORCAMI ${ }^{1}$
}

AgATA WóJCIK

Wydział Sztuki, Uniwersytet Pedagogiczny im. KEN w Krakowie Faculty of Art, Pedagogical University in Cracow agata.wojcik@up.krakow.pl

Artyści i teoretycy, którzy w 1901 roku powołali do życia Towarzystwo Polska Sztuka Stosowana (TPSS), stawiali przed sobą trzy zasadniczy cele, zapisane w statucie organizacji: „szerzenie zamiłowania do polskiej sztuki stosowanej, ułatwianie jej rozwoju i wprowadzanie jej do przemysłu" 2 . Cele te zostały sprecyzowane i rozszerzone w pierwszym sprawozdaniu z działalności Towarzystwa, w którym pojawiły się informacje, że zadaniem jego będzie także „budzenie oryginalnej twórczości w dziedzinie sztuki zastosowanej do przemysłu i budownictwa i nadanie jej cech odrębności narodowej, a zarazem stworzenie niezbędnej do tego atmosfery rodzimej i nastroju artystycznego"3. W niniejszym artykule spróbuję zaprezentować tę część działalności Towarzystwa, która miała na celu nawiązanie współpracy z producentami i warsztatami, a także uzyskanie zleceń instytucji oficjalnych i osób prywatnych. Współpraca ta polegała na ogłaszaniu za pośrednictwem TPSS konkursów, dostarczaniu projektów lub zatrudnianiu twórcy w charakterze kierownika artystycznego.

1 Artykuł powstał w ramach projektu badawczego „Ojcowie polskiego designu. Towarzystwo Polska Sztuka Stosowana. Architektura wnętrz i meblarstwo” finansowanego przez Narodowe Centrum Nauki (2015/17/D/HS2/01215).

2 Statut Towarzystwa „Polska Sztuka Stosowana”, Kraków 1901, s. 1.

3 Sprawozdanie Towarzystwa „Polska Sztuka Stosowana” w Krakowie 1901-1902, Kraków 1903, s. 4. 
Działacze TPSS dążyli do nawiązania współpracy pomiędzy artystami a drukarniami i wydawnictwami ${ }^{4}$. Chcieli w ten sposób propagować dbałość o wszelką formę druku, która zaowocować miała odnową polskiego projektowania graficznego. Już w 1902 roku TPSS zorganizowało konkurs dla drukarni Piotra Laskauera w Warszawie na komplet dwudziestu czterech liter i ozdoby drukarskie ${ }^{5}$. Za projekty inicjałów nagrodzono Jana Bukowskiego, a za ozdoby - Kazimierza Purzyckiego ${ }^{6}$. Pojawiały się też konkursy związane z projektami konkretnych publikacji. W 1903 roku Eugeniusz Dąbrowa-Dąbrowski zaprojektował inicjały i ozdoby drukarskie, a Bukowski okładkę książki Adolfa Dygasińskiego Gody życia (Wydawnictwo Juliana Marchlewskiego w Monachium; il. 1)7. Także Bukowski w 1905 roku wygrał konkurs firmy Altenberga na okładkę, exlibris i papier okładkowy książki Kultura polska (il. 2). Poza tym artyści związani z TPSS nawiązali współpracę z drukarniami Anczyca, Uniwersytetu Jagiellońskiego i Władysława Teodorczuka w Krakowie, które używały inicjałów, ozdób i okładek artystycznych o „charakterze polskim”. Sukcesem było także objęcie przez artystów z kręgu TPSS funkcji kierownika artystycznego bądź nawiązanie dłuższej współpracy z kilkoma drukarniami. Bukowski pracował w Drukarni Uniwersytetu Jagiellońskiego ${ }^{10}$, Antoni Procajłowicz tworzył dla Drukarni Narodowej, Henryk Uziembło i Anna GramatykaOstrowska projektowali dla Drukarni Teodorczuka, a Karol Frycz nawiązał

${ }^{4}$ Zob. A. Wójcik, Towarzystwo Polska Sztuka Stosowana i odnowa polskiego projektowania graficznego początku XX wieku, „Biuletyn Historii Sztuki” 2016, nr 4, s. 623-649.

5 Drobne rzeczy, „Architekt” 1902, nr 12, szp. 167.

“II. sprawozdanie Towarzystwa „Polska Sztuka Stosowana” w Krakowie. R. 1903, Kraków 1904, s. 9.

7 Ibidem, s. 10.

8 Konkurs artystyczno-drukarski, „Czas” 1905, nr 102, s. 1; Biblioteka Akademii Sztuk Pięknych w Krakowie, teki Jerzego Warchałowskiego, sygn. 20029, karta 134: Rozstrzygnięcie konkursu, „Czas” 1905; „Sztuka Stosowana. Wydawnictwo Towarzystwa »Polska Sztuka Stosowana" w Krakowie" 1907, z. 10, s. 44.

9 II. sprawozdanie Towarzystwa „Polska Sztuka Stosowana”..., op. cit., s. 6-7.

10 III. sprawozdanie Towarzystwa "Polska Sztuka Stosowana” w Krakowie. R. 1904, Kraków 1905, s. 8. 


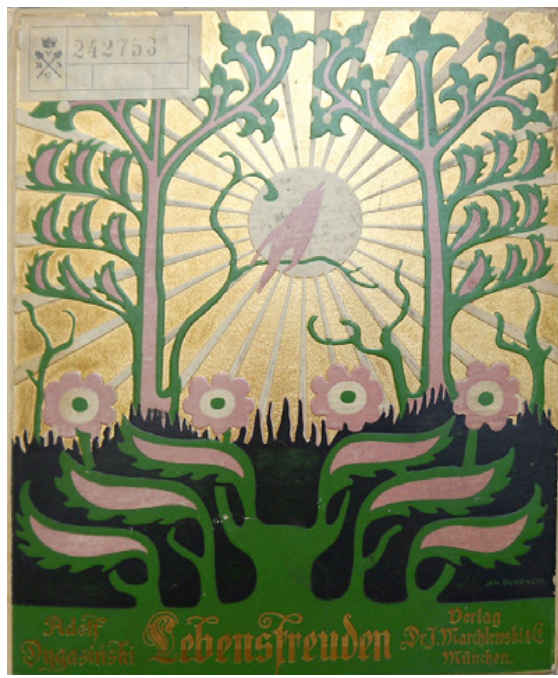

Il. 1. Okładka książki Gody życia Adolfa Dygasińskiego projektu Jana Bukowskiego, wydawca: Julian Marchlewski, Monachium 1903

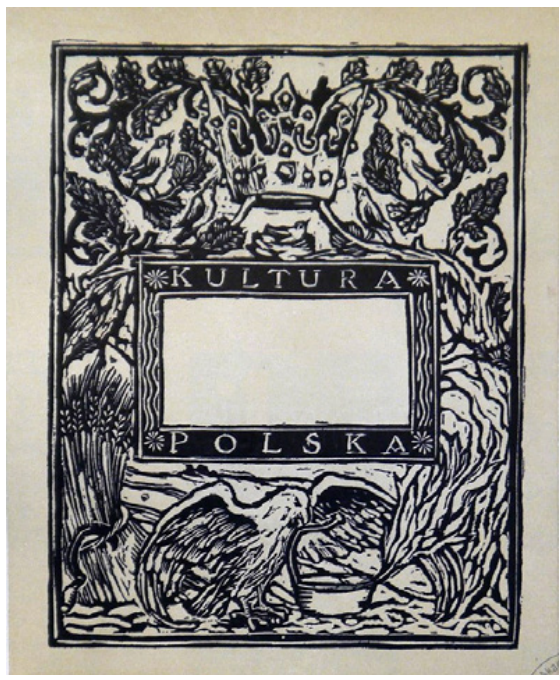

Il. 2. Projekt okładki książki Kultura polska autorstwa Jana Bukowskiego, wydawnictwo Altenberga

współpracę z Drukarnią Anczyca ${ }^{11}$. TPSS starało się pośredniczyć pomiędzy instytucjami publicznymi i firmami prywatnymi a artystami-projektantami. Efektem były plakaty, losy, exlibrisy, znaki drukarskie. Ze współpracy z TPSS skorzystały między innymi: Muzeum Narodowe w Krakowie, Towarzystwo Szkoły Ludowej, zdrojowisko w Swoszowicach, browar księcia Sanguszki w Tarnowie, kaliski Związek Hodowców Bydła, fabryka dachówek i cegły „Burtyn”. Z czasem ogłaszano coraz mniej konkursów na projekty druków, co było pozytywnym wynikiem, zawiązała się bowiem nić współpracy między artystami, firmami i odbiorcami ${ }^{12}$. Dzięki działalności Towarzystwa wielu artystów malarzy (Uziembło, Bukowski, Frycz, Procajłowicz oraz Edward Trojanowski) zaczęło działać w dziedzinie projektowania graficznego

11 J. Sowiński, Sztuka typograficzna Młodej Polski, Wrocław 1982, s. 66.

12 IX. sprawozdanie Towarzystwa "Polska Sztuka Stosowana” w Krakowie. R. 1910, Kraków 1911, s. 7-8. 
i zrozumiało, jak pisał Franciszek Mirandola, że „równym zaszczytem tu być pierwszym, jak w tak zwanej "sztuce czystej «"13.

Z sukcesem starano się nawiązać współpracę z warsztatami tkackimi. Już w pierwszym roku działalności przyjęto ofertę współpracy z Włodzimierzem Pohlmannem, właścicielem warsztatów tkackich z Lipnicy. Dostarczono mu sześć wzorów na kilimy i dywany strzyżone, które następnie wystawiono w warszawskiej „Zachęcie” w 1902 roku. Wszystkie egzemplarze znalazły nabywców. Ostatecznie jednak nie podpisano z Pohlmannem umowy o stałej współpracy ${ }^{14}$. Epizodycznie, począwszy już od roku 1903, dostarczono też wzorów warsztatom Konstancji Lipowskiej w Nowym Sączu ${ }^{15}$. Stałą współpracę TPSS nawiązało z warsztatami Antoniny Sikorskiej w Czernichowie ${ }^{16}$. Umowa uwzględniała 50\% czystego zysku dla TPSS. Sprzedażą kilimów miała zająć się sama właścicielka warsztatu. Towarzystwo mogło także zbierać zamówienia na kilimy i sprzedawać je w swojej siedzibie - wówczas pobierało 5\% prowizji (il. 3-4). Artyści-projektanci mieli otrzymać „połowę czystego zysku [...] po potrąceniu 5\% na rzecz Towarzystwa”, jednakże w czasie trwania umowy nie mogli wykorzystać wzorów przekazanych Sikorskiej do tworzenia projektów dla innych producentów. Na każdym kilimie Sikorska powinna uwzględnić informację, że projektu dostarczyło TPSS ${ }^{17}$. Współpraca przyniosła wymierne efekty - do roku 1903 wykonano w Czernichowie około sto sześćdziesiąt kilimów, ich łączna wartość wyniosła trzy tysiące koron ${ }^{18}$. TPSS popularyzowało wyroby czernichowskie, prezentując je na wystawach organizowanych w Krakowie i Warszawie. Stały się one także wizytówką Towarzystwa za granicą: w roku 1906 pokazano je

13 F. Mirandola, Pierwsza polska wystawa drukarska, „Poradnik Graficzny” 1905, nr 1, szp. 7.

${ }^{14}$ Sprawozdanie Towarzystwa „Polska Sztuka Stosowana”..., op. cit., s. 10.

15 II. sprawozdanie Towarzystwa „Polska Sztuka Stosowana”..., op. cit., s. 7.

16 Zob. I. Goldman, Kilimy Józefa Mehoffera, „Biuletyn Historii Sztuki” 2009, nr 3, s. 389-399; B. Biedrońska-Słota, Kilimy i batiki z pracowni krakowskich (1900-1930) w zbiorach Muzeum Narodowego w Krakowie, Kraków 2004; Fin de siècle w Krakowie: grafika użytkowa, tkaniny, rzemiosło artystyczne ze zbiorów Muzeum Narodowego w Krakowie, red. B. Biedrońska-Słota, Kraków 2005.

${ }_{17}$ Sprawozdanie Towarzystwa „Polska Sztuka Stosowana”..., op. cit., s. 10-12.

18 II. sprawozdanie Towarzystwa „Polska Sztuka Stosowana”..., op. cit., s. 7. 


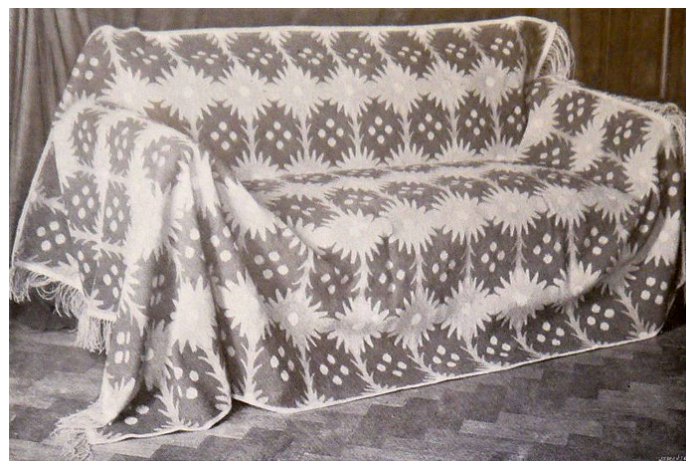

Il. 3. Klim projektu Edwarda Trojanowskiego, warsztat kilimkarski Antoniny Sikorskiej w Czernichowie

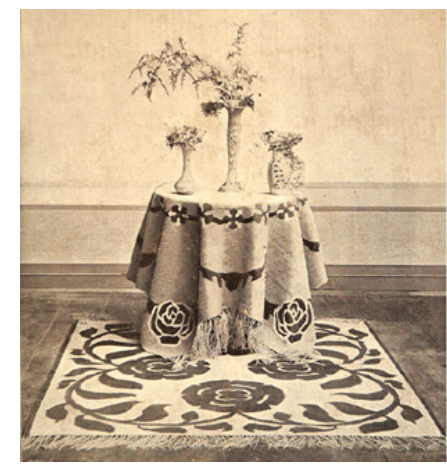

Il. 4. Kilimy projektu Kazimierza Brzozowskiego, warsztat kilimkarski Antoniny Sikorskiej w Czernichowie, wazy majolikowe projektu Jana Szczepkowskiego, Fabryka Niedźwiedzkiego i Spółki na Dębnikach

w Londynie i w Wiedniu ${ }^{19}$. Sprzedawano je również na wiedeńskim bazarze wyrobów przemysłu krajowego ${ }^{20}$.

Na początku funkcjonowania TPSS można odnotować niewielki sukces w dziedzinie meblarstwa: Krajowa Szkoła Koszykarska w Skołyszynie wykonała dwa komplety mebli projektu Franciszka Bruzdowicza ${ }^{21}$, pokazano je następnie na wystawie jubileuszowej Towarzystwa Politechnicznego we Lwowie oraz na wystawie TPSS w Warszawie w 1902 roku i część z nich została sprzedana ${ }^{22}$. Nie nawiązano jednak stałej współpracy. Od początku działalności artyści z kręgu TPSS dostarczali wzorów na meble zamawiane przez osoby prywatne ${ }^{23}$. Aby pozyskać projekty mebli i dekoracji wnętrz, TPSS ogłaszało konkursy i odezwy, na przykład w 1903 roku rozpisało

19 V. sprawozdanie Towarzystwa „Polska Sztuka Stosowana” w Krakowie. R. 1906, Kraków 1907, s. 9.

20 Kronika, „Czas” 1904, nr 25, s. 2.

${ }^{21}$ Zob. A. Feliks, Meble plecione w Polsce 1864-1939, Warszawa 2018.

22 Sprawozdanie Towarzystwa „Polska Sztuka Stosowana”..., op. cit., s. 10-12.

${ }^{23}$ II. sprawozdanie Towarzystwa „Polska Sztuka Stosowana”..., op. cit., s. 4; III. sprawozdanie Towarzystwa „Polska Sztuka Stosowana”..., op. cit., s. 4. 


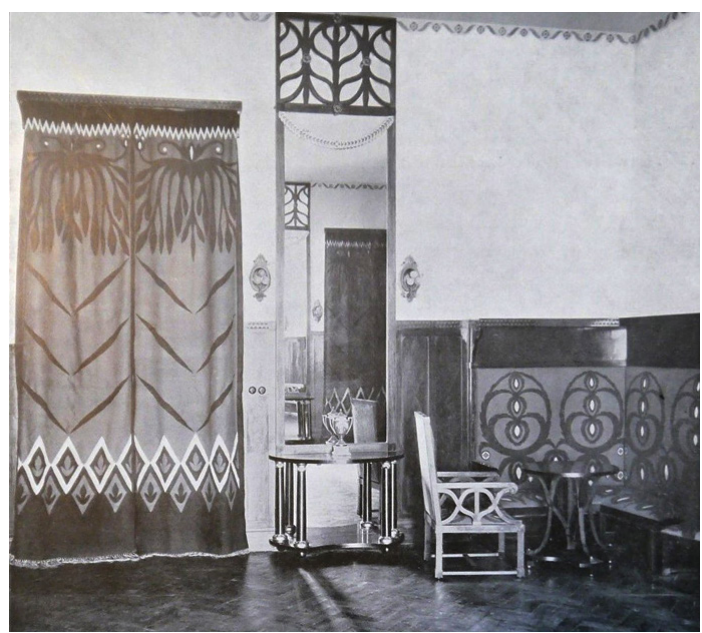

Il. 5. Przedpokój w mieszkaniu prezydenta miasta Krakowa Juliusza Leo projektu Józefa Czajkowskiego; meble i boazeria - warsztat Michała Pieli w Krakowie; kilimy i obicia mebli - warsztat kilimkarski Antoniny Sikorskiej w Czernichowie odezwę, której celem było pozyskanie projektów mebli do dowolnego pokoju ${ }^{24}$, stołu i stołka do jadalni, a także kanapy i fotela do bawialni ${ }^{25}$; w 1904 roku ogłosiło konkurs na meble i dekorację gabinetu męskiego ${ }^{26}$, oczekiwano jednak jakiegoś większego i bardziej prestiżowego zlecenia z dziedziny meblarstwa i dekoracji wnętrz. Przełomem stało się powierzenie TPSS w 1905 roku zaprojektowania wnętrz restauracji w Starym Teatrze w Krakowie ${ }^{27}$. Wnętrza te, reprodukowane i opisywane później na łamach prasy, zachęciły prywatnych zleceniodawców do korzystanie z usług TPSS. W kolejnych latach (1905-1908) Towarzystwo dostarczało projekty mebli i wnętrz osobom prywatnym ${ }^{28}$. Zamówienia

24 Rozstrzygnięcie konkursu i wystaw, „Architekt” 1903, nr 5, szp. 60; II. sprawozdanie Towarzystwa „Polska Sztuka Stosowana”..., op. cit., s. 10.

25 II. sprawozdanie Towarzystwa „Polska Sztuka Stosowana”..., op. cit., s. 10; Tow. „Polska Sztuka Stosowana”, „Czas” 1903, nr 254, s. 2; Z Towarzystwa „Polska sztuka stosowana”, „Architekt” 1903, nr 11, szp. 120.

26 Biblioteka Akademii Sztuk Pięknych w Krakowie, teki Jerzego Warchałowskiego, sygn. 20029, karta 108.

27 Zob. A. Wójcik, „Myśl artystyczna”, która przeniknęła do „knajp”. Wnętrza restauracyjne $w$ Starym Teatrze $w$ Krakowie projektu artystów zwiąanych $z$ Towarzystwem Polska Sztuka Stosowana, „Modus. Prace z Historii Sztuki Instytutu Historii Sztuki Uniwersytetu Jagiellońskiego” 2018, t. 18, s. 123-149.

28 IV. sprawozdanie Towarzystwa „Polska Sztuka Stosowana” w Krakowie. R. 1905, Kraków 1906, s. 3-4; V. sprawozdanie Towarzystwa „Polska Sztuka 
takie pozwoliły na zaprezentowanie na wystawie w warszawskiej „Zachęcie” w 1908 roku całego zespołu wnętrz. Pojawiły się także bardziej prestiżowe zlecenia, np. projekty pokoi w mieszkaniu krakowskiego prezydenta Juliusza Leo $^{29}$ (il. 5), wnętrza sanatorium dra Dłuskiego w Zakopanem ${ }^{30}$, wreszcie biura i sali posiedzeń krakowskiego magistratu ${ }^{31}$.

Zlecenia, które Towarzystwo pozyskało od krakowskiego magistratu, skłoniły instytucje i osoby prywatne do zamawiania projektów mebli i wnętrz bezpośrednio u artystów z kręgu TPSS; przykładem może być Henryk Uziembło, który projektował wnętrza Hotelu Krakowskiego we Lwowie, Teatru Świetlnego „Uciecha” w Krakowie czy Teatru „Bagatela” w Krakowie ${ }^{32}$. TPSS nie nawiązało stałej współpracy z żadną fabryką mebli, artyści, realizując swoje projekty z dziedziny meblarstwa, współpracowali bezpośrednio z wybranymi warsztatami stolarskimi. Dużym uznaniem

Stosowana”..., op. cit., s. 4; VI. Sprawozdanie Towarzystwa „Polska Sztuka Stosowana" w Krakowie. R. 1907, Kraków 1908, s. 4; VII. sprawozdanie Towarzystwa „Polska Sztuka Stosowana”. R. 1908, Kraków 1909, s. 4;

29 V. sprawozdanie Towarzystwa „Polska Sztuka Stosowana”..., op. cit., s. 4. Wykonano przedpokój projektu Józefa Czajkowskiego i jadalnię projektu Ludwika Wojtyczki.

30 Zob. A. Wójcik, Mikrokosmos polskiej sztuki użytkowej początku XX wieku. Wystrój wnętrz sanatorium i willi doktorostwa Bronisławy i Kazimierza Dłuskich w Zakopanem, "Quart. Kwartalnik Instytutu Historii Sztuki Uniwersytetu Wrocławskiego" 2018, nr 3, s. 34-64.

${ }^{31}$ X. sprawozdanie Towarzystwa „Polska Sztuka Stosowana” w Krakowie. R. 1911, Kraków 1912, s. 7. Zaproponowano artystom urządzenie biur prezydenta miasta, wiceprezydentów, dyrektora magistratu, a także sali posiedzeń i poczekalni. Projekty gabinetów wykonali: Dąbrowa-Dąbrowski, Frycz i Uziembło, sale reprezentacyjne zaprojektował Józef Czajkowski. Realizacja przedłożonych projektów okazała się jednak zbyt kosztowna dla magistratu. Ostatecznie zdecydowano, by powierzyć zaprojektowanie gabinetu prezydenta Bukowskiemu, również związanemu z TPSS.

32 Zob. K. Nowacki, Wnętrza Henryka Uziembły, „Zeszyty Naukowe Muzeum Historycznego m. Krakowa "Krzysztofory«" 1977, t. 4, s. 39-53; idem, Secesyjne sale i budynki kino-teatralne w Krakowie, „Biuletyn Historii Sztuki” 1973, nr 3-4, s. 331-334; idem, Architektura krakowskich teatrów. Dzieje teatru w Krakowie, Kraków 1982. 


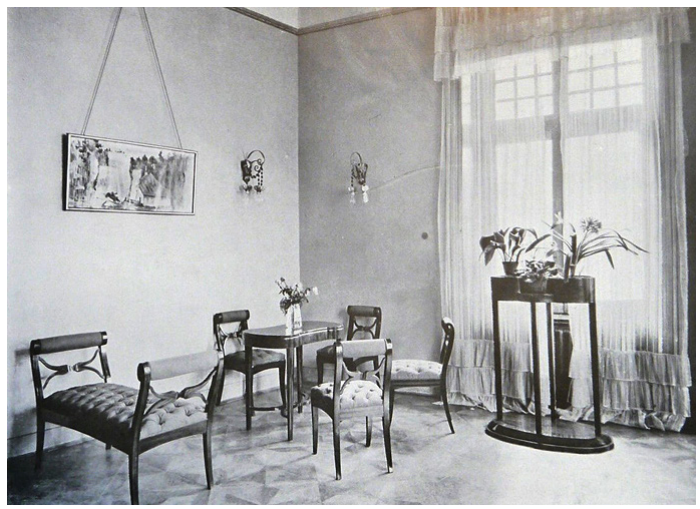

Il. 6. Salon $w$ mieszkaniu Antoniego Suskiego w Krakowie projektu Ludwika Wojtyczki; meble - warsztat Andrzeja Sydora $w$ Krakowie

cieszyły się krakowskie warsztaty Andrzeja Sydora, Michała Pieli, Józef Zabrzdy (Zabżdy), braci Ligęzów, Józefa Sperlinga i innych (il. 6).

Członkowie Towarzystwa starali się współpracować też z innymi branżami. Oddziaływali zwłaszcza na zaprzyjaźnionych przedsiębiorców krakowskich. Monografistka Fabryki Fajansów J. Niedźwieckiego i S-ki w Dębnikach przypuszcza, że Adam Kirchmayer podjął produkcję artystycznej majoliki pod wpływem Jerzego Warchałowskiego i Jana Szczepkowskiego ${ }^{33}$. Stałym współpracownikiem fabryki został Szczepkowski, co skrupulatnie odnotowano w sprawozdaniach TPSS ${ }^{34}$. Towarzystwo starało się promować ceramikę z Dębnik, prezentując ją na wystawach (Kraków 1905) i reprodukując w wydawanych zeszytach ${ }^{35}$. Nawiązano także więź współpracy z Zakładem Witraży i Mozaik Stanisława Gabriela Żeleńskiego. Jego kierownikiem artystycznym został aktywny działacz TPSS - Jan Bukowski; wkrótce

33 B. Kołodziejowa, Fabryka Fajansów J. Niedźwieckiego i Ski w Dębnikach pod Krakowem (1900-1910), „Rocznik Muzeum Mazowieckiego w Płocku” 1973, R. 3, s. 9-10.

34 III. sprawozdanie Towarzystwa „Polska Sztuka Stosowana”..., op. cit., s. 8; B. Kołodziejowa, Fabryka Fajansów J. Niedźwieckiego i Ski..., op. cit., s. 5-45.

35 Katalog nowożytnych tkanin i wyrobów ceramicznych, Kraków 1905; „Sztuka Stosowana. Wydawnictwo Towarzystwa "Polska Sztuka Stosowana « w Krakowie", 1906, z. 8-9. 
zastąpił go na tym stanowisku Henryk Uziembło ${ }^{36}$. Za pośrednictwem TPSS Zakład Żeleńskiego ogłosił w roku 1909 konkurs na dekorację kaplicy na Kahlenbergu ${ }^{37}$. TPSS starało się zainteresować możliwością współpracy również producentów wyrobów metalowych. Przykładem może być konkurs na elektryczną lampę mosiężną na biurko i wiszącą, ogłoszony w kwietniu 1907 roku $^{38}$. Nagrodzony został projekt Szczepkowskiego ${ }^{39}$. Wykonano ją w krakowskiej fabryce Marcina Jarry.

Mimo zamierzeń działaczom Towarzystwa nie udało się bezpośrednio wpłynąć na produkcję przemysłową. Największy rozmach miała produkcja ceramiki w Dębnikach, kilimów w Czernichowie oraz witraży i mozaik Gabriela Żeleńskiego, jednakże wszystkie te działania nadal nosiły znamiona ekskluzywnego rzemiosła artystycznego. W obliczu braku zainteresowania producentów członkowie TPSS nawoływali do założenia „warsztatów wzorcowych”, w których artyści będą ściśle współpracować z rzemieślnikami. TPSS chciało dokonać odnowy rynku, zalanego miernej jakości przedmiotami, które polscy rzemieślnicy produkowali, powielając zagraniczne wzory. Warchałowski widział w podniesieniu jakości rzemiosła zadanie dla artystów. Uważał, że: „Ciągły, swobodny kontakt fachowo wykształconych rzemieślników z artystą, daje najlepsze rezultaty, wnosząc do warsztatów urok artystycznego ideału"40. Za wzór stawiał kursy prowadzone w muzeach przemysłowych na Zachodzie Europy przez Petera Behrensa i Richarda Riemerschmieda. Niestety, TPSS nie mogło znaleźć osoby ani instytucji, która sfinansowałaby utworzenie warsztatów. Upatrywało miejsce dla takich warsztatów w Muzeum Techniczno-Przemysłowym w Krakowie i czynnie uczestniczyło w dyskusji nad jego reformą. To zamierzenie zrealizowano

${ }^{36}$ I. Buchenfeld-Kamińska, Ścienne malarstwo sakralne Jana Bukowskiego w Krakowie, [w:] Sztuka sakralna Krakowa w wieku XIX, red. W. Bałus, J. Wolańska, Kraków 2010, s. 221.

37 Biblioteka Akademii Sztuk Pięknych w Krakowie, teki Warchałowskiego, sygn. 20028, karta 65: Konkurs na urządzenie i dekoracją kaplicy Sobieskiego przy kościele na Kahlenbergu pod Wiedniem, 1 VII 1909.

38 Konkurs na lampy, „Czas” 1907, nr 93, s. 2.

39 VI. sprawozdanie Towarzystwa „Polska Sztuka Stosowana”..., op. cit., s. 5-6; Rozstrzygnięcie konkursu, „Czas” 1907, nr 126, s. 1.

40 J. Warchałowski, O sztuce stosowanej, Kraków 1904, s. 28. 
ostatecznie dopiero w 1913 roku, gdy powołano do istnienia Warsztaty Krakowskie ${ }^{41}$.

Przedmioty projektowane przez artystów z kręgu TPSS publiczność odbierała często jako drogie, ekskluzywne, a nierzadko - niefunkcjonalne. Przykładem tego mogą być komentarze na temat mebli pokazanych w Towarzystwie Zachęty Sztuk Pięknych w 1908 roku. Pisano na przykład: „[...] sprzęty ładne jako pomysły konstrukcyjne, są wytworne zestawienia barw, zgrabnie rysowane desenie, lecz tego nie dość... A gdzie tam na wystawie »człowiek średnio-zamożny «"42. Szczególnie zwracały uwagę meble do mieszkania Zofii i Tadeusza Żeleńskich projektu Stanisława Wyspiańskiego, o których reporterka pisała: „[...] robią [...] wrażenie, że ja bym się tych mebli - bała. Są jakieś dziwaczne, ostre, sztywne. Nie zapraszają. Odstraszają" "33, a inny dziennikarz notował: „ciężkie, masywne [...], które nazwać można anti-burżuazyjnymi ze względu na ich posępną surowość, kanciastość, okrutność przegubów i niesiedzistość" ${ }^{44}$. TPSS zmieniło swoją postawę, przygotowując wnętrza na wystawę „Architektury i wnętrz w otoczeniu ogrodowym” w Krakowie w 1912 roku. Przygotowano nie tylko wnętrza dworku podmiejskiego, ale także domów włościanina, robotnika i rzemieślnika. Do mieszkania robotnika i rękodzielnika Karol Maszkowski i Franciszek Mączyński zaprojektowali meble o prostej formie, pozbawione nadmiaru dekoracji, wykonane $z$ litego drewna, ale wielofunkcyjne i dostosowane do małej przestrzeni. Sprzęty te, powszechnie chwalone przez krytyków, bliskie były meblom projektowanym przez Bruno Paula i Richarda Riemerschmidta. Mogłyby stać się prototypami mebli dla średniozamożnych sfer ${ }^{45}$.

41 Zob. I. Huml, Warsztaty Krakowskie, Wrocław 1973.

42 Bibliotek Akademii Sztuk Pięknych w Krakowie, teki Warchałowskiego, sygn. 20029, karta 198, 199; S. Popowski, Sztuka stosowana, „Gazeta Codzienna” 1908.

43 Bibliotek Akademii Sztuk Pięknych w Krakowie, Teki Warchałowskiego, sygn. 20029, karta 197, L. Kotarbińska, Wystawa Sztuki Stosowanej w Krakowie, „Kurier Literacki”, 10 II 1908.

44 A. Nowaczyński, Sztuka stosowana w Warszawie, „Prawda” 1908, nr 6, s. $69-70$.

${ }^{45}$ Zob. A. Wójcik, Projekty wnętrz i mebli zaprezentowane na wystawie "Architektury i wnętrz w otoczeniu ogrodowym” w Krakowie w 1912 roku, „Roczniki Humanistyczne" 2019, z. 4, s. 109-137. 
Artyści z kręgu TPSS odnieśli niezamierzony sukces komercyjny. Producenci i rzemieślnicy zauważyli, że przedmioty projektowane przez członków TPSS wzbudzają zainteresowanie, zaczęli więc zapełniać rynek niskiej jakości technicznej i artystycznej przedmiotami imitującymi oryginały. Zżymali się na to twórcy związani z TPSS - Trojanowski tak pisał do „Kuriera Warszawskiego”: „Pomysły istotnych artystów przyswajane są bez najmniejszej ceremonii przez - byle kogo, i skoszlawione, pofuszerowane, przeinaczone dowolnie idą...”. Wspominał, że w Warszawie można zakupić kilimy będące zniekształconą kopią prac Karola Tichego, bowiem niekorzystnie zmieniono ich kolorystykę ${ }^{46}$. Zwrócił także uwagę, że w warszawskiej kawiarni Słowiańskiej można zobaczyć kopie mebli do jadalni Żeleńskich projektu Wyspiańskiego. Ich autorem był Jerzy Stanisław Węgierkiewicz, który twierdził, że jego projekt jest „przystosowaniem tak zwanej "wyspiańszczyzny" do celów praktycznych"47.

W 1910 roku podsumowano działalność TPSS i wskazano polskiej sztuce stosowanej cele na przyszłość. Pisano, że mimo początkowego niezrozumienia, dzięki inicjatywom Towarzystwa „doszło [...] do niezaprzeczonego wpływu na społeczeństwo w rzeczach sztuk i rzemiosł", szczególnie dobrze rozwinęły się takie gałęzie sztuki jak witraż, kilimkarstwo, projektowanie druków ${ }^{48}$. W mniej optymistycznym tonie pisano w kolejnym sprawozdaniu, że nie udało się wywrzeć wpływu na przemysłowców, którzy nie widzą potrzeby „produkcji maszynowej, opartej na nowoczesnych podstawach, a dążącej do rozpowszechnienia wyrobów tanich a w dobrym guście". Sądzono, że należy w przyszłości tworzyć dwa typy przedsiębiorstw, pierwsze, których celem będzie produkowanie rzeczy „doborowych pod względem wzoru, materiału i wykonania”, i drugie - przedsiębiorstw „dla produkcji maszynowej”, które będą tworzyć rzeczy tanie, lecz „bez obniżenia gustu i dobroci wykonania" ${ }^{\prime 49}$.

${ }^{46}$ C. Jankowski, Myi „styl wspótczesny”, „Kurier Warszawski” 1912, nr 18, s. 2-3.

47 Idem, W sprawie swojskiego zdobnictwa, „Kurier Warszawski” 1912, nr 27, s. 13.

48 IX. sprawozdanie Towarzystwa „Polska Sztuka Stosowana”..., op. cit., s. 3-6.

49 X. sprawozdanie Towarzystwa „Polska Sztuka Stosowana”..., op. cit., s. 4-7. 


\section{Bibliografia}

II. sprawozdanie Towarzystwa „Polska Sztuka Stosowana” w Krakowie. R. 1903,

Towarzystwo „Polska Sztuka Stosowana”, Druk W.L. Anczyca i Spółki, Kraków 1904.

III. sprawozdanie Towarzystwa „Polska Sztuka Stosowana” w Krakowie. R. 1904,

Towarzystwo „Polska Sztuka Stosowana”, Druk W.L. Anczyca i Spółki, Kraków 1905.

IV. sprawozdanie Towarzystwa „Polska Sztuka Stosowana” w Krakowie. R. 1905,

Towarzystwo „Polska Sztuka Stosowana”, Druk W.L. Anczyca i Spółki, Kraków 1906.

V. sprawozdanie Towarzystwa „Polska Sztuka Stosowana” w Krakowie. R. 1906,

Towarzystwo „Polska Sztuka Stosowana”, Druk W.L. Anczyca i Spółki,

Kraków 1907.

VI. sprawozdanie Towarzystwa „Polska Sztuka Stosowana” w Krakowie. R. 1907,

Towarzystwo „Polska Sztuka Stosowana”, Druk W.L. Anczyca i Spółki, Kraków 1908.

VII. sprawozdanie Towarzystwa „Polska Sztuka Stosowana” w Krakowie. R. 1908,

Towarzystwo „Polska Sztuka Stosowana”, Druk W.L. Anczyca i Spółki,

Kraków 1909.

IX. sprawozdanie Towarzystwa „Polska Sztuka Stosowana” w Krakowie. R. 1910,

Towarzystwo „Polska Sztuka Stosowana”, Druk W.L. Anczyca i Spółki, Kraków 1911.

X. sprawozdanie Towarzystwa „Polska Sztuka Stosowana” w Krakowie. R. 1911,

Towarzystwo „Polska Sztuka Stosowana”, Druk W.L. Anczyca i Spółki, Kraków 1912.

Biblioteka Akademii Sztuk Pięknych w Krakowie, teki Jerzego Warchałowskiego, sygn. 20029, karta 134: Rozstrzygnięcie konkursu, „Czas” 1905.

Biblioteka Akademii Sztuk Pięknych w Krakowie, teki Jerzego Warchałowskiego, sygn. 20029, karta 108.

Biblioteka Akademii Sztuk Pięknych w Krakowie, teki Jerzego Warchałowskiego, sygn. 20028, karta 65: Konkurs na urządzenie i dekoracją kaplicy Sobieskiego przy kościele na Kahlenbergu pod Wiedniem, 1 VII 1909.

Biblioteka Akademii Sztuk Pięknych w Krakowie, teki Warchałowskiego, sygn. 20029, karta 198, 199: Stefan Popowski, Sztuka stosowana, „Gazeta Codzienna" 1908. 
Biblioteka Akademii Sztuk Pięknych w Krakowie, Teki Warchałowskiego, sygn. 20029, karta 197: Lucyna Kotarbińska, Wystawa Sztuki Stosowanej w Krakowie, „Kurier Literacki” 10 II 1908.

Beata Biedrońska-Słota, Kilimy i batiki z pracowni krakowskich (1900-1930) w zbiorach Muzeum Narodowego w Krakowie, Muzeum Narodowe w Krakowie, Kraków 2004.

Irena Buchenfeld-Kamińska, Ścienne malarstwo sakralne Jana Bukowskiego w Krakowie, [w:] Sztuka sakralna Krakowa w wieku XIX, red. W. Bałus, J. Wolańska, TAiWPN Universitas, Kraków [cop. 2010].

Drobne rzeczy, „Architekt” 1902, nr 12.

Anna Feliks, Meble plecione w Polsce 1864-1939, Instytut Sztuki PAN, Warszawa 2018.

Fin de siècle w Krakowie: grafika użytkowa, tkaniny, rzemiosło artystyczne ze zbiorów Muzeum Narodowego w Krakowie, red. B. Biedrońska-Słota, Muzeum Narodowe w Krakowie, Kraków 2005.

Izabela Goldman, Kilimy Józefa Mehoffera, „Biuletyn Historii Sztuki” 2009, nr 3. Irena Huml, Warsztaty Krakowskie, Zakład Narodowy im. Ossolińskich, Wrocław 1973.

Czesław Jankowski, My i „styl współczesny”, „Kurier Warszawski” 1912, nr 18.

Czesław Jankowski, W sprawie swojskiego zdobnictwa, „Kurier Warszawski” 1912, nr 27.

Katalog nowożytnych tkanin i wyrobów ceramicznych, Druk. „Czasu”, Kraków 1905. Bolesława Kołodziejowa, Fabryka Fajansów J. Niedźwieckiego i Ski w Dębnikach pod Krakowem (1900-1910), „Rocznik Muzeum Mazowieckiego w Płocku” 1973, R. 3.

Konkurs artystyczno-drukarski, „Czas” 1905, nr 102.

Konkurs na lampy, „Czas” 1907, nr 93.

Kronika, „Czas” 1904, nr 25.

Franciszek Mirandola, Pierwsza polska wystawa drukarska, „Poradnik Graficzny” 1905, nr 1.

Kazimierz Nowacki, Secesyjne sale i budynki kino-teatralne w Krakowie, „Biuletyn Historii Sztuki” 1973, nr 3-4.

Kazimierz Nowacki, Wnętrza Henryka Uziembły, „Zeszyty Naukowe Muzeum Historycznego m. Krakowa »Krzysztofory«" 1977, t. 4.

Kazimierz Nowacki, Architektura krakowskich teatrów. Dzieje teatru w Krakowie, Wydawnictwo Literackie, Kraków 1982. 
Adolf Nowaczyński, Sztuka stosowana w Warszawie, „Prawda” 1908, nr 6. Rozstrzygnięcie konkursu, „Czas” 1907, nr 126.

Rozstrzygnięcie konkursu i wystaw, „Architekt”1903, nr 5.

Janusz Sowiński, Sztuka typograficzna Młodej Polski, Ossolineum, Wrocław 1982. Sprawozdanie Towarzystwa „Polska Sztuka Stosowana” w Krakowie 1901-1902, Druk W.L. Anczyca i Spółki, Kraków 1903.

Statut Towarzystwa „Polska Sztuka Stosowana”, Druk W.L. Anczyca i Spółki, Kraków 1901.

„Sztuka Stosowana. Wydawnictwo Towarzystwa »Polska Sztuka Stosowana« w Krakowie" 1906, z. 8-9.

„Sztuka Stosowana. Wydawnictwo Towarzystwa »Polska Sztuka Stosowana» w Krakowie" 1907, z. 10.

Tow. „Polska Sztuka Stosowana”, „Czas” 1903, nr 254.

Jerzy Warchałowski, O sztuce stosowanej, Towarzystwo „Polska Sztuka Stosowana”, Kraków 1904.

Agata Wójcik, Mikrokosmos polskiej sztuki użytkowej początku XX wieku. Wystrój wnętrz sanatorium $i$ willi doktorostwa Bronisławy $i$ Kazimierza Dłuskich w Zakopanem, „Quart. Kwartalnik Instytutu Historii Sztuki Uniwersytetu Wrocławskiego" 2018, nr 3.

Agata Wójcik, „Myśl artystyczna”, która przeniknęła do „knajp”. Wnętrza restauracyjne $w$ Starym Teatrze $w$ Krakowie projektu artystów związanych $z$ Towarzystwem Polska Sztuka Stosowana, „Modus. Prace z Historii Sztuki Instytutu Historii Sztuki Uniwersytetu Jagiellońskiego” 2018, t. 18.

Agata Wójcik, Projekty wnętrz i mebli zaprezentowane na wystawie „Architektury $i$ wnętrz w otoczeniu ogrodowym” w Krakowie w 1912 roku, „Roczniki Humanistyczne" 2019, z. 4 [w druku].

Agata Wójcik, Towarzystwo Polska Sztuka Stosowana i odnowa polskiego projektowania graficznego początku XX wieku, „Biuletyn Historii Sztuki” 2016, nr 4. Z Towarzystwa „Polska sztuka stosowana”, „Architekt” 1903, nr 1.

Źródła ilustracji

Il. 1. Archiwum autorki.

Il. 2. „Sztuka Stosowana” 1907, z. 10.

Il. 3 i 5. „Sztuka Stosowana” 1907, z. 10.

Il. 4. „Sztuka Stosowana” 1906, z. 8-9.

Il. 6. „Sztuka Stosowana” 1909, z. 13. 


\section{The Artistic Activity of the Polish Applied Art Society between 1901 and 1903. Attempts at Cooperation between Manufacturers, Designers and Consumers}

Active between 1901-1903, the Polish Applied Art Society (the TPSS), sought to achieve three essential aims: 'to spread admiration for Polish applied art, to facilitate its development and to introduce it to the industry'. This article presents the activities of the TPSS, whose aim was to establish cooperation with manufacturers and workshops as well as to acquire commissions from institutions and private individuals. Under this cooperation, the TPSS opened competitions, provided designs or employed artists as artistic directors. The Society succeeded in establishing cooperation with a number of printing and publishing houses; it also finalised an agreement with Antonina Sikorska's kilim workshop, Czernichów. What is more, by employing TPSS members as artistic directors, it exerted influence on ceramics manufacturing in J. Niedźwiecki \& Co. Faience Factory in Dębniki and on that of stained glass in Stanisław Gabriel Żeleński’s Stained Glass and Mosaic Works in Krakow. The TPSS was also commissioned to design interiors and furniture by private individuals and by institutions. However, no cooperation was established with any furniture factory. Contrary to its plans, the Society did not succeed in directly influencing furniture manufacturing; its activities had the features of exclusive artistic craft. This is also how they were received by the audience. Summing up and closing its activities, the Society set a goal for Polish applied art, which would be to create two types of businesses ones which would manufacture things 'of quality, in design, material, and workmanship' and others for 'machine manufacturing' and producing cheap objects without, however, 'lowering standards of taste and workmanship'.

Keywords: the Polish Applied Art Society, design, applied art, kilims, furniture, graphic design 